\title{
FOLKLORE AND IDENTITY: THE SITUATION OF LATVIA
}

\author{
$\underline{\text { Aldis Putelis }}$
}

I will start with the statement that my own self-awareness is a divided one - on one hand it is that of an average Latvian, knowledgeable of the origins, history and culture of his nation, on the other that of a scholar, scrutinising and doubting all the same concepts. So I can serve as an object of study for myself. But the study of the Latvian folklore involves not only scholarly aspects - there is an age-old tradition of using folklore in forming and creating phenomena of social and political sphere. Gradually a kind of secondary folklore is developed - a set of ideas based on interpretation of original material, with these ideas replacing the original ones.

This is the question of folklore and fakelore as Richard Dorson has put it. Notions like folklore, myth and mythology are extremely difficult to define, as both the phenomenon to be defined and the understanding of what are the features to be described by a definition change in the course of time. What could be looked upon as a "faked folklore" before, becomes just a "recent variant" in some time - depending on the prevailing understanding of the standards a folklore item should comply with. This involves all the complexity of defining the group folklore belongs to or is carried by. Latvians still believe it to be nation as a whole - beyond any doubt.

As I once described that - the people in Latvia are much more fond of beautiful legends than scholarly study which cannot provide them with such; in fact depriving them of those legends as ungrounded. The whole field of folklore studies in Latvia is still to some extent subject to the ideal task of providing the nation with the proof of its ancient culture and strengthening its national consciousness. This task has been assigned to Latvian folkloristics since the moment of its emergence. Thus to an average Latvian it would sound strange that there are neither celebrations of the sesquicentennial of the term "folklore" nor widely known folklorists in England - the country were the notion originated, therefore supposedly having a strong tradition. On the other hand one might also say that folklore study in Latvia follows principles that were dominating the field in Europe at least several decades ago. Such an evaluation would have been true, but there is also an explanation for this rooted in the political and demographic situation in Latvia. With the language and culture of Latvians being under threat of assimilation for centuries, with the social and cultural life in Latvia having been dominated by foreigners - in one form or another - folklore has been the only indigenously Latvian cultural source, turned into the backbone of Latvian modern culture.

Actually, this could be the point to end a description of Latvian folkloristics and identity making process, as that is all what can be said in general and the task of explaining a nation's consciousness to people belonging to a different nation is a Sisyphean task. And I apologise in advance as the necessity to just mention at least all the important issues might leave too little space for explanation and analysis.

At the end of the XII century first German missionaries appeared on the soil of the modern-day Latvia. Soon afterwards they were followed by crusaders, and baptising of the pagans by use of sword and fire - as it is referred to in the Latvian tradition - began. The locals were fighting the intruders, but also rather frequently - their own neighbours (in alliance with the German knights), so the tribes which later formed modern Latvians were never united. Therefore pretty soon the fight was over in favour of conquerors who had better military skills and techniques. Thus the Latvians have never had a great king of their own ruling a united country or any greater part of it as the Lithuanians have. But the fight is remembered as a heroic one, with all the available evidence of the 
battles won being extracted from the ancient chronicles and cherished. Also the unsuccessful attempts are remembered - like that of kursi - the tribe from (modern) Western Latvia - coming in their boats to destroy the German stone-built town of Riga. Kursi had some experience of such warfare at that time as it is obvious from the chronicles and recorded prayers of the Nordic people the Vikings. Allegedly there is a prayer for deliverance from fire, storm and kursi. And sometimes $\mathrm{I}$, as a descendant of this tribe, am rather proud of my ancestors having been threat to the warriors of such well-established fame.

Here the notion of myth is to be mentioned once again. In Latvia this notion has mostly preserved the original meaning of a story narrating the origins of the world and the deities. But here we confront myths in the more modern sense - as some narrative or idea used to back a particular social phenomenon, based on history, but created for the purpose and therefore non-verifiable, but depending on public credibility. For this pre-German period is believed to be the golden age of Latvians, with general prosperity, freedom and unspoiled, i.e. uninfluenced culture being the main ideal features. At the same time the paganism of Latvians was a political myth created and maintained by the intruders, as in the Western Latvia the Christianity was introduced by Danes in the X century, but by the time of German invasion many chieftains of Vidzeme - 'Midlands' - were subjects of Russian duchies and at least nominally christianised. And this is just one example of the complexity of the issue.

There might be at least some ground for the pride of the Latvians in having preserved their language and their own ways. The Latvians did not disappear like the third Baltic nation (?; tribe?) - the Old Prussians. On the other hand it might be just the result of different historical circumstances beyond the influence of the would-be Latvians.

As the conquerors considered themselves of higher social status, they did not merge with the local people who were made serfs. Neither did they show any interest in their customs and lifestyle. The main aim was to make the serfs work - and attend church on Sundays. As many examples nowadays show, formal Christianity is no obstacle for retaining tribes own rituals and traditions, in fact it takes a long time even to introduce any 'proper Christianity'. So it is believed that the Christianity had very weak impact on Latvian traditions, customs and rituals for a rather long period, giving the opportunity to trace the original unspoiled Latvian ways. The situation changed with the Reformation, when the need for church services in Latvian came into being. With that came also the attempts of the Germans to "enlighten" their subjects, what proves the fact of modern life having passed them unnoticed. There are brilliant descriptions of the Latvian festivals, customs and rituals, just with one remark - they are compiled by German pastors to show how savage the locals are.

The Latvians were not looked upon as a nation, but as a social class instead; the division in Latvians and Germans was not built on the actual nationality, but on belonging of a person to the class, as the only available education higher than primary was German - even as late as the end of the XIX century. Therefore any educated person was "a German", while the Latvians were the uneducated. It was extremely difficult for a Latvian to enter the "Germans". They had to break all relations with the Latvians, even by trying to enter the better families through marriage. The language a person spoke was of extreme importance, so they spoke German even at home. Although hated by the Latvians and designated karkluvaciesi ('willow Germans') they knew that was the only way to reach a higher social status.

Things changed dramatically in the middle of the XIX century. Feudal system had outlived its time, still the Germans were content with their position and suspicious towards the changes in the society, which could affect the ständische Ordnung. It was the time for the first educated Latvians to emerge. As it was explained above, at the time the dominating principle was "born a Latvian, but 
became a German through education"(*1). Curiously enough also these Latvians were sponsored by their German landlords who could have expected them to turn into "Germans" later. They were disobedient enough to try the opposite. If Garlieb Merkel (1769-1850), who wrote a book showing the miserable situation of the Latvians under their cruel masters, received a tombstone with an inscription of Garlibs Merkelis, latvis ('A Latvian'), Krisjanis Valdemars (1825-1891), the leader of the jaunlatviesi movement ('Young Latvians'; parallel to Young Czechs or Young Germans and designated so by a German - pastor Brasche) dared to indicate his Latvianness on the calling card on his room door at the Dorpat University. Not to delve into the complex history of emergence of the jaunlatviesi movement, Valdemars' case can be taken as an ultimate expression of the change - a Latvian, sponsored by a German patron, announced that even after acquiring his "German" education he is a Latvian (a contradictio per se taking into account the present-day situation of the period). This angered the rulers to such an extent, that although in private correspondence statements like the following were made:

Those who know 'our nationals' (unsere Nationale - synonymous to 'barbarian') have long lost all hope for the Latvian people. It is a stillborn nation. The Latvians have no national past and no history, they cannot have a future. The only character traits which distinguish them are their totally backward and crippled language ... and their blinding hatred for the Germans. (*2)

This was written in 1860's by the same pastor Georg Brasche in a letter to the President of LettischLiterärische Gesellschaft, of which Brasche himself was an outstanding representative. This society was made up by Germans interested in study of Latvian customs and language, as well as in "enlightenment" of Latvians. On one hand Brasche's statement is well-grounded - Latvians have no glorious past; the modern culture including production techniques, towns and urban life, writing and even grammar of the Latvian language was introduced by the Germans, the Latvian language has preserved many features similar to those of Latin, therefore out-of-date. On the other hand - the German rulers were responsible for this state of the Latvians and that "blinding hatred" was as wellgrounded taking into account just the attitude expressed in the above quote.

So the Latvians had to prove their rights as a nation, the existence of their identity, their particular features, which could not be denied. But national identity is an international idea, a general scheme to be filled with particular contents suitable for this idea. The time when Young Latvians faced their task was the time of 'epic nations' and the ideas of antiquity revisited. So on one hand jaunlatviesi had to and continued propagating the ideas of the modern age among their nation - to help them achieve the same cultural level as that of the established nations (a similar task was undertaken before by the Germans, with the aim to replace the 'savage' ways of the Latvians).

On the other hand they became extremely interested in Latvian oral culture as the only indigenously Latvian source. The Latvian customs and songs had been recorded for already more than two hundred years, as the first Latvian folksong - both the characteristic stanza of four octosyllabic lines and the melody - was published by Fredericus Menius in his work De origine Livonorum in 1632. (The same poetical structure is still alive and can be observed and collected nowadays, so supposedly - it was much more abundant one and a half centuries ago.) The interest of the local educated men - practically only of German origin - had been strengthened by Johann Gottfried Herder, of whose working in Rìga for 5 years the Latvians are also proud, supposing that the Latvian singing traditions influenced the development of Herder's views. Actually Herder can be looked upon as the founder of the folkloristics as we know it as the idea of the voice of a nation expressed in its songs belongs to him as well.

By mid XIX century the first published Latvian folksong stanza and a couple of sentences in Latvian to be found in guild registers and the documents of witch trials were complemented by 
several collections of 'the best Latvian folksongs' arranged by the German pastors. The collection work was now taken over by the Latvians themselves. Thus the first inherent contradiction appeared, as in words of the German scholar Otto Böckel 'Reading is the enemy of singing'. The historical situation demanded to overcome this contradiction and achieve the two goals at the same time - to bring the knowledge of modern culture to the Latvians and to cultivate and collect the oral culture material. As a proof of rights it was of enormous importance for the nation-to-be although it could be looked upon also as a proof of an out-dated way of life. But there was already the Finnish example of Kalevala. Although the Finns are proud of having never been serfs, in many aspects the situation was very similar to that in Latvia.

It soon turned out that the Latvian oral tradition does not contain material useful for the arrangement into the form of an epic. But after the Finns and the Germans themselves had epics of their own being 'an epic nation' was a historical imperative. While searching for the explanation of this lack, the Young Latvian poets started creating a Latvian Olympus in their poetry, using every material available, mostly that of the German chronicles. The result was an impressive amount of false deities introduced, but in its deeper sense this attempt was the same as that of Juris Alunans (1832-1864), expressed in his Dziesmizas ('The Poems'). This book contained poetry of world authors translated and localised to show the very possibility of the Latvian language to express emotions and ideas the same as the well-known languages. To prove the existence of a golden age, it was at least useful to provide the evidence in the form of mythology as sophisticated as that of ancient Greece and Rome.

The man to be mentioned especially in the connection with the collection of the Latvian folksongs is Krisjanis Barons (1835-1923). An astronomer and mathematician by education, friend of the mentioned above Valdemars, active participant of the movement he took over the material previously collected by another Young Latvian Fricis Brivzemnieks-Treuland. Later designated as "the cornerstone of the Latvian philology" the edition Latvju Dainas $(\underline{* 3})$ compiled and arranged by Barons is extremely demonstrative.

The image of Barons nowadays is that of a wise old man with grey hair and beard - very similar to that of the Finnish singer of runes or that of Latvian supreme God. Entitled 'Father of Songs' Barons is occupying a significant place also in the modern Latvian culture and honoured for his ingenious principle of text arrangement in the edition as well as his careful editorial work having supposedly changed nothing in the texts originally received. Sometimes in some poetic exaggeration even the collection of the whole material published is attributed to him. In a poll organised a year ago in order to establish the 33 books considered by the Latvians as most important for them, Latvju Dainas occupied the 4th position. Folksongs are taught at school as a part of literature curriculum; everybody to any extent involved in the folklore studies knows the 'sacred number' of 217,996 - the number given by Barons of folksongs included in the edition, as well as the fact that "every Latvian has a folksong of his own" - the number of the currently collected folksongs texts is approximately the same as that of the living Latvians (ca. 1,300,000). Dainas are used in different studies of the Latvian antiquity as well as in modern poetry. The main qualities of the ancient Latvian have been established from them and namely: ancient Latvian has been diligent and modest, has understood and obeyed the laws of nature, honoured the live beings and plants around him, his most favoured colour being that of cleanliness in every sense - white. The manuscript of Latvju Dainas in the form of a special cupboard designed by Barons himself has also achieved the status of a national symbol.

That is the generally known truth - or myth if you like it that way. Scholarly facts, which are less legendary as it was suggested above, are different from those. Of course, Barons has not collected his edition himself, it is a work of hundreds of collectors, with different attitudes, but still mainly that of creating the monument to the heritage of the nation, therefore less valuable material could be 
omitted. The personality of an informant was rarely of interest, it simply was not the aim of the work. While transcribing the collected texts, errors arouse on behalf of the persons employed as Barons could not do that alone. Barons himself was found to have 'improved' the texts, sometimes adding a line, sometimes replacing some part of the text, sometimes separating the sequences of quatrains, sometimes recreating them. Still, we can argue that he acted like an informant just as one having an enormous memory. But in his famous "Cupboard of Dainas" with seventy drawers there is one less known to the general public and even those engaged in study - it is marked as 'Christian nonsense' and contains thousands of texts mentioning explicitly Christian notions. These have not been included in the edition, although they seem to be included in the previously mentioned 'sacred number', thus making it fictitious.

Demonstrative is also the very choice of the title. How it is obvious from the correspondence of Barons, the word daina, in fact a Lithuanian one for 'song', was suggested by Barons' collaborator Visendorfs, who actually undertook the fund-raising and did not take any part in editing. This was intended to show the historical links to the Lithuanians, who have had much more of glorious past than their Northern neighbours, although there was no proof of the word ever been used in Latvian.

So Latvju Dainas appeared - published in the period between 1894 and 1915, in six volumes/eight tomes. The main principle according to which the texts were arranged is the course of the human life from the birth to the burial rites, as the ritual usage of the texts was the main guideline for Barons. Whether intentionally or not it makes the wedding song sequence similar to that of Kalevala.

Barons was the representative of Young Latvians to outlive all of his friends. In 1890's the ideas widespread among the newly-formed Latvian intelligentsia had changed as well and become more socialist and Marxist- oriented. Collection of folklore at that time had already become a target for ridicule as a backward activity. Although correct from the perspective of the Böckel's principle mentioned above, this attitude did not prove appropriate from the historical perspective.

The first National Awakening, as this period of the forming of the very notion of Latvians as a nation was later entitled, was followed by the second - when in turmoil after the World War I an independent Latvian state came into being. The need in Latvian culture was strongly felt; the example was already there. Barons edition was reprinted (in 1922-1923), in 1924 Latviesu folkloras kratuve (the Archives of Latvian Folklore) was founded (now the oldest academic institution in Latvia). It collected folklore from the regions of Latvia, not represented in Latvju Dainas (half of Latvia's parishes), organised study and publication of the material collected. There was no doubt that such an institution is vitally necessary for Latvia. It was established following the Finnish pattern, with Kaarle Krohn coming over to lecture on principles applicable in the work of such archives.

The idea of Latvians having preserved the cultural traits dating back to the period of Indo-European age had become that of general domain. There were different attempts to prove the past significance of the Latvian tribes for the rest of the Europe, based on the Latvian folksongs as material less influenced in the recent centuries because of its strict form. When in 1927-1932 a rival edition to Latvju Dainas was published, it consisted of about the same texts just differently arranged, but complemented with articles written by experts of some particular field - like physicians, civil engineers, etc. - analysing the life of the ancient Latvians as it is depicted in folksong texts. Still the most illustrative example of the usage of dainas is the creation of the Latvian national religion Dievturiba on the material of the song texts. The central figure in this movement was Ernests Brastins (1892-1940?). 
As it is obvious from his works, he was a person of strong national orientation. He joined the Latvian Army during the fight for the independence, he was the leader of an archaeological field party studying the castles and settlements in the whole territory of Latvia (this deed of his is still appraised by Latvian archaeologists), published studies of Latvian ornament, compiled an index of mythological notions for the Archives of Latvian Folklore. The main idea of his activities seems to be expressed in the most concentrated form in the following quote: "Emphasising the differences in dresses, furniture, buildings, customs and art inside our borders we add a step to the great pace of the world's culture. Thus we justify the borders we have established in the name of our particularity/difference. We had no other right to do so." (*4) There is also another expression by Brastins: "Let's be cautious with Europe! Let's admire it, but not be too enthusiastic! "(도)

Together with some other educated Latvians, Brastins, an artist himself, in 1920's came to a conclusion that religion plays an extremely significant part in the consciousness-forming of a nation, although overlooking the actually international character of the religions observed. On the contrary he stresses the internationality of the Christianity, which - more to it - was forcibly introduced by conquerors using it as an excuse for the invasion. As a result of this a "national Latvian religion" Dievturiba appeared. First publication - a small booklet entitled Latvju dievestibas atjaunosana ('Restoration of the Latvian religion') appeared in 1925, soon afterwards the first 'parish' was organised. Its name could be translated as 'possession of God; honouring God'. In the preface to the most elaborate compilation of its ideas Dievturu cerokslis (1932) Brastiðs wrote: "My nation! You are the luckiest among all nations! You still have a religion of your own, which is the best in the world. Its truth has thousands of years of age, but it is eternal... We have to chose between two alternatives: either to perish as a nation or to become Latvian again. We have no other way... It is true that Dievturiba destroys something of Europe's. But those are not the values of Europe, on the contrary, those are its deepest delusions. The great duty of our nation with which we are entrusted by God is to reintroduce the Aryan-Latvian religion, for it to be returned to Aryan Europe." ( $(\underline{6})$ The exaggerations might have been deliberate in order to achieve publicity. Whether 'Aryan Europe' had any notorious connotations cannot be proved.

Dievturiba in fact is a free arrangement of ideas found in different song texts, freely chosen from the corpus of Latvju Dainas. To a great extent it is just the Christian framework filled with different contents or the same ideas declared having actually originated in pre-Christian times and later included in the Christianity. To demonstrate their primarity dievturi introduced their own calendar by adding ten thousand years (or just one digit) to the existing one. The teaching contains internal contradictions, what is inevitable for such a short period of development, but those are of less importance as vision of Latvian folksongs as a source for a religious consciousness leaves enough space for every particular individual to create his own vision.

Still, some particular traits are always present and strong, with the first being the hostility to the Christianity. Secondly, Dievturiba claims to be a reasonable, nearly scholarly built system. To a great extent the idea of the importance of dainas as the only indigenous source as well as their great age was cultivated by Dievturiba, so was also the set of the basic features of a Latvian. Although the number of dievturi was not big and their beliefs did not reach the position of the state religion in Latvia, the influence of their ideas is much greater.

Whatever the number of adherents and the social importance of Dievturiba, in 1940, with the ruling powers changing as Latvia was incorporated in the Soviet Union, Brastins simply disappeared. His exact death date has not been certified. It is just one more proof that ideology occupied an important place in the policies of the Soviet Union. 
Latviesu folkloras kratuve functioned until 1944. The actual archive was evacuated from Riga, but fortunately enough the attempt to transport it to a seemingly more secure location overseas was just thought of. A number of former staff members were also still in Latvia, so the work was restarted under a different name in 1945. Although the traditional Latvian folklore was declared in the better case 'pre-soviet', in the worst 'bourgeois-nationalist', it could not be denied its existence. With the emphasis on the songs (and other material) on social relations and work, the study was still carried on. We might announce the soviet folklorists to be the first to discover the contemporary folklore as demand to collect either revolutionary or "soviet folklore" was in the first place, but the traditional folklore remained in at least partial rights. So it lead to such amazing examples as the most ancient singing style (still alive) to be combined with the texts where the word novads 'the district; the farmland belonging to or cultivated by one farmstead' is substituted by kolhozs 'the collective farm'.

To show the world the happiness and well-being of the soviet nations the rulers had to allow the traditions to carry on. So was the case of Kalevala festivities in Karelia, so the song festivals in the Baltics. It started in Latvia in 1864 with a festival of local choirs in Vidzeme. In fact it was created to prove the capability of the Latvians for a European (=German) cultural activity, and that of the appropriately arranged Latvian folk tunes to reach a high artistic level. The festival bringing together thousands of performers, nurturing patriotic, national feelings reached all-Latvia range and became regular, with participation and attendance growing especially in the independent Latvia. After the war the patriotic songs were still there, just they were different songs intended to express a different kind of patriotism - the soviet one. Propaganda of 'bourgeois nationalism' was a crime grave enough for serious court sentences, therefore nobody (or almost) tried to introduce the national symbols at the official festival. Designation of anything or anybody as "nationalist" had equally grave consequences as that of "young Latvian" a century ago. But the very fact of thousands of Latvians being together, whatever songs they are singing, was an expression of national feelings. Actually the official performers and audience merged in the public transport while returning from the festival site. And there are legends told on what was the singing and dancing like at the places of accommodation of singing groups from outside Riga.

The tradition of ethnographic ensembles had originated already in the independent Latvia. In mid 1970 's the movement of folklore groups - town people interested in folklore performance - widened. The ideas of the 'New Age' together with those of Dievturiba were present there. In the beginning of 1980 's the movement was really widespread, in 1985 came the sesquicentennial of Barons with wide celebration. With the glasnost in force and Latvian Popular Front formed, in 1988 the International Folklore Festival Baltica was to take place in Latvia. The opportunity for selfexpression through folklore performance as well as the fact of representatives from many countries visiting Latvia just because of a folklore event fascinated the masses - audience was enormous, streets of the city - crowded. This was also the event when the Latvian national flag - strictly banned from any public appearance in any form, including artwork - reappeared in the streets of Rìga, carried by a member of a folklore group, not a leader of a political party - maybe it was somewhat the same. Curiously enough, the song they sang was a localisation of the German Wacht am Rhein. The third awakening - Atmoda - was gaining force, involving all of the heritage of the previous two.

The interest in folklore is still significant in Latvia. Dievturiba is still known among Latvians, both in Latvia, where it has the rights equal to those of any other religion, and among the Latvians in exile. It could be understood also as a parallel to the present general interest in antiquity in the world, e.g. the neo-paganism and groups like Society for Creative Anachronism. There are still singers in Latvia having learned their songs the same way as their great-grand parents - from oral tradition. Barons in his preface to Latvju Dainas wrote that "...our songs are vanishing together with 
the old women singing them..." This seems still the situation, a hundred years later. The Finns are said to have lost their last rune singers in 1960's. Taking into account that Barons was born in the year when the first Kalevala was published we might consider an interval of time equal to the lifespan of one generation to be the difference between the processes in Latvia and Finland. But it is not likely for Latvian traditional folklore to see its demise so soon.

Still the existence of the traditional folklore is a peculiar one. With the actual original circumstances for its functioning being lost long since, the old songs are recorded from the descendants of those who performed them in any actual ritual event. Folklore is considered as a valuable heritage of the past, thus excluding both recent genres and "fakelore" from the study. E.g. in Latvia study of modern phenomena like contemporary legends is still looked upon as something not serious and purposeless. It can be done for amusement like telling jokes or singing songs at a party table, although most frequently these are not the ancient folksongs but rather the localised German ones. There is a secondary layer, folklore about folklore, what is of general availability, many amateurs studying the material in order to prove either the greatness of the Latvians themselves or their relations to some great figures of the past like the Druids. It might be said that every Latvian feels there is some ancient wisdom, some ancient spirit in the Latvian folksongs. And although it might take not too great an effort of a scholar to prove that actually not much of real antiquity is present there, is it worth that effort?

\section{References}

1.Arveds Svabe 1959. Latvijas vesture 1800-1914 (History of Latvia 1800-1914); Stockholm: Daugava 1959, p. 365; quoted from Janis Arveds Trapans 1989. Krisjanis Barons. His Life and Times. Linguistics and poetics of Latvian Folk Songs. McGill-Queen's University Press 1989, p. 18.

2. ibid, p. 369-370, quoted from Trapans 1989, p. 21.

3. Latvju Dainas 1894-1915, vol. I-VI. Jelgava and St. Petersburg.

4. Brastins, E. 1925. Latvju raksta kompozicija (The Composition of the Latvian Ornament). Rìga.

5. Brastins, ibid.

6. Brastins, E. 1932. Dievturu cerokslis jeb Teoforu katekisms, tas ir senlatviesu dievestibas apcerejums (The Catechism of the Dievturi). Riga, (11932), p. 3. 